\title{
20. ORGANIC GEOCHEMISTRY LEG 41, INTRODUCTION AND SUMMARY
}

\author{
Keith A. Kvenvolden, U.S. Geological Survey, Menlo Park, California
}

Organic geochemical studies were conducted on samples from four of five sites drilled off West Africa. Samples from Sites 367 and 368 permitted comparison of several geochemical parameters in sediments from the Cape Verde Basin and Cape Verde Rise, respectively. A bonus at Site 368 was the presence of diabase sills that had intruded Cretaceous black shale. Shale adjacent to these sills has been affected by this volcanic activity, and the samples collected provide a means of studying thermal alteration of organic matter. Samples from Site 369 are from the continental slope and samples from Site 370 come from deep basinal sediments.

The papers that follow consider various organic geochemical aspects of the sediments including their petroleum-generating potential, the effects of diagenesis with particular emphasis on thermal alterations associated with igneous intrusions, and the composition of light hydrocarbon gases.

It is generally agreed that many of the sediments examined could be considered potential source rocks of petroleum, but most of the organic matter, except that in sediments associated with the igneous intrusive rocks, is thermally immature. The organic matter is composed of both marine and terrestrially derived substances, as indicated by microscopic examinations and carbon isotopic compositions of kerogen and lipids.

Intrusion of diabase sills has caused dramatic alterations in the organic matter of adjacent shale, but these alterations decrease rapidly away from the sills. Changes were noted in the content of organic carbon and extractable organic material, in the distribution of hydrocarbons, and in the reflectance of vitrinite. Transformation of porphyrins and the occurrence of petroporphyrins were observed. Variations in electron paramagnetic resonance spectra were found to be associated with the thermal history of the sediments. Gases in sediments near the intrusives were probably derived from thermal decomposition of organic material and from biogenic sources. Gases in other parts of the sections were mainly biogenic. Both molecular and isotopic compositions support these suggestions. 